Niğde Ömer Halisdemir Üniversitesi Mühendislik Bilimleri Dergisi
Niğde Ömer Halisdemir University Journal of Engineering Sciences

\title{
Comparison of mechanical and geometrical properties of octet lattice structures using the electron beam melting
}

\section{Elektron ışın eritme yöntemi kullanılarak sekizli kafes örgüi yapılların mekanik ve geometrik özelliklerinin karşılaștırılması}

\author{
Bilçen Mutlu Mitil ${ }^{1, *}$ (iD \\ ${ }^{1}$ Marmara University, Mechanical Engineering Department, 34722, İstanbul Turkey
}

\begin{abstract}
Additive manufacturing methods allow to produce complex geometries such as lattice structures. Aim of this study is to identify octet truss lattice structure's mechanical capabilities. Firstly, octet truss structure designed and used to fill specimens. Specimens 1, 2 and 4 with wall and lattice structure, specimen 3 only with lattice structure and also a filled specimen are modelled. Modelled tensile specimens are additively manufactured from Ti-6Al-4V with Electron Beam Melting method. A comparison between specimens having same structural design (1,2 and 4) has been made to gain insight about consistency of EBM method. Tensile experiments have been made with all of the specimens and tensile strength difference that can be considered significant determined among specimen 1, 2\&4. Specimen 3 resulted not to be a practical approach as it showed poor tensile strength values. Lastly, tensile stress results of filled specimen are shared and compared with the other types of specimens. These results are providing a good sight for assessment of both octet truss structure and EBM manufacturing technology.
\end{abstract}

Keywords: Lattice structures, Octet truss, Ti-6Al-4V, Additive manufacturing

\section{Introduction}

$3 \mathrm{D}$ printing of metals, additive manufacturing (AM), is a process that produces 3-dimensional geometries layer-bylayer until the whole shape is acquired. This technology gives the opportunity to manufacture complex geometries. With this opportunity, much more optimized part designs can be achieved especially in terms of weight reduction. Different requirements of different designs resulted appearing of various types of AM methods. One of these AM methods is powder bed fusion (PBF). It offers great dimensional accuracy in producing complex-shaped parts as can be seen in Figure 1.

Electron Beam Melting is a type of PBF manufacturing. It differs from the other PBF systems with its energy source. Most of the other systems are using laser as an energy source while EBM uses electron beam. An advantage of EBM process over the other PBF processes is lower residual stress effect on the parts [2, 3]. Considering residual stresses
Özet

Katmanlı üretim yöntemleri, kafes yapıları gibi karmaşık geometrilerin üretimine izin veren yeni bir teknolojidir. Bu çalışmanın amacı sekizli kafes yapısının mekanik özelliklerini belirlemektir. İlk olarak, kafes yapısı oluşturulmamış ve tamamen dolu bir numune kullanılmıştır. 1,2 ve 4 numaralı numuneler duvar kalınlıkla kafes yapıdan modellenmiş, yalnızca 3 numaralı numune duvar kalınlıklı sekizli kafes yapısından oluşturulmuştur. Modellenen çekme numuneleri, Elektron Işını Eritme yöntemi ile Ti-6Al-4V'den malzeme kullanılarak üretilmiştir. $\mathrm{EBM}$ yönteminin tutarlılığı hakkında fikir edinmek için aynı yapısal tasarıma (1, 2 ve 4) sahip numuneler arasında bir karşılaştırma yapılmıştır. 1, 2 ve 4 numaralı numuneler arasında önemli sayılabilecek gerilme mukavemeti farkı belirlenmiștir. Numune 3, zayıf gerilme mukavemeti değerleri göstermiştir. Son olarak, doldurulmuş bir numunenin çekme gerilmesi sonuçları paylaşılmış ve diğer numunelerin sonuçlarıyla karşılaşıırılmıştır. Bu sonuçlar hem sekizli kafes yapısı hem de EBM üretim teknolojisinin değerlendirilmesi açısından önemlidir.

Anahtar kelimeler: Kafes yapıları, Sekizli örgü kafes yapılar, Ti-6Al-4V, Eklemeli imalat

mostly effects the fatigue life of the parts, this advantage of EBM makes it more attractive than the other PBF methods.

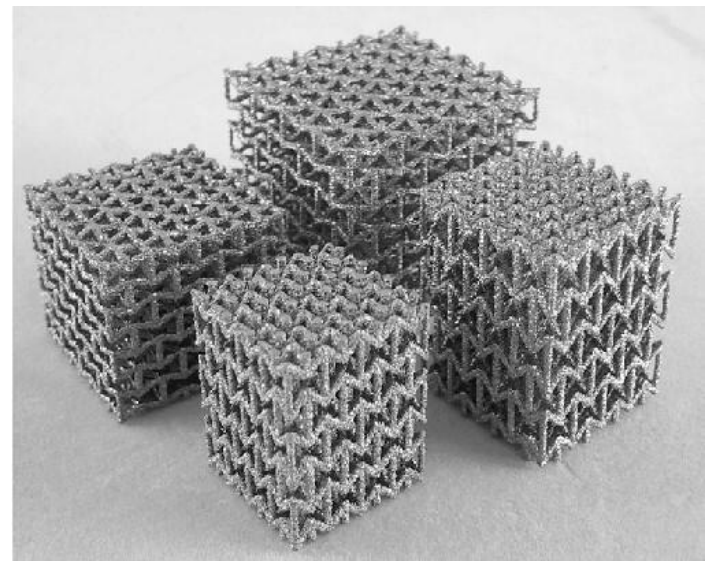

Figure 1. EBM produced lattice structures [1]

\footnotetext{
* Sorumlu yazar / Corresponding author, e-posta / e-mail: bmutlu@ marmara.edu.tr (B. Mutlu Mitil) Gelis / Recieved: 08.04.2021 Kabul / Accepted: 11.08.2021 Yayımlanma / Published: 14.01.2022 doi: $10.28948 /$ ngmuh. 911834
} 
Octet truss structures have not been thoroughly explored in the past, and, hence, we chose to conduct this study [412]. The octet truss lattice structure is illustrated in Figure 2. Fuller (1961) researched this structure and prepared the most detailed report of its properties [13]. The octet truss was offered as a method of 3D field filling with an efficient truss structure in a variable cell size. The nodes form a specially defined face-centred cubic structure, as shown in Figure 2(b).

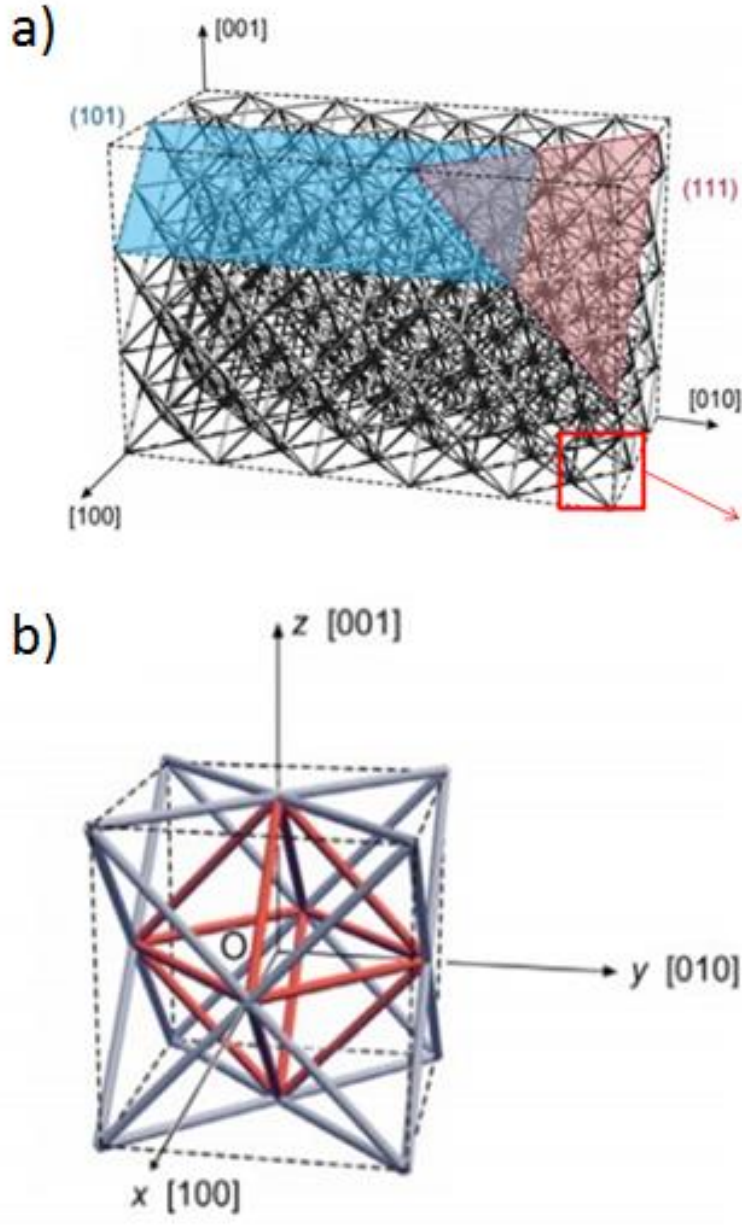

Figure 2. (a) 3D packaging of unit cells constructing an octet truss. (b) A centric octahedral cell composed of 12 struts that have 8 tetrahedrons at their boundaries. This composes a unit cell of the face-centred cubic crystal-symmetry in the octet truss lattice. The intersection of 12 struts is a node of the octet truss [8].

Dong et al. (2015) used snap-fit and vacuum brazing method in order to produce $2 \%$ to $\% 16$ relative density octettruss lattice structures from Ti-6Al-4V sheets. The study proved that octet-truss structures performs better than mechanical properties over other cellular materials [8]. Deshpande et al. (2001) [9] made a research on aluminium alloy casted octet-truss structures and the results showed that these structures can be alternative against metallic foams with the aim of obtaining lightweight structures [9]. It is extremely efficient to use lattice structures comprising octet trusses for the production of high-density materials, as they provide high performance [14]. Li et al. (2008) [15] studied lattice block which is investment casted with aerospace quality. Experiments under compression, bending and impact points that high strength and ductility can be reached [15]. Figure 3 illustrates the raw material Ti-6Al-4V, Al-7Si$0.3 \mathrm{Mg}$ [9], and Ti-6Al-2Sn-4Zr2Mo alloys [15, 16], for the space modelling lattice structures under the densitydependent modulus of compression load and foams with low density (metal, polymer, and alumina).
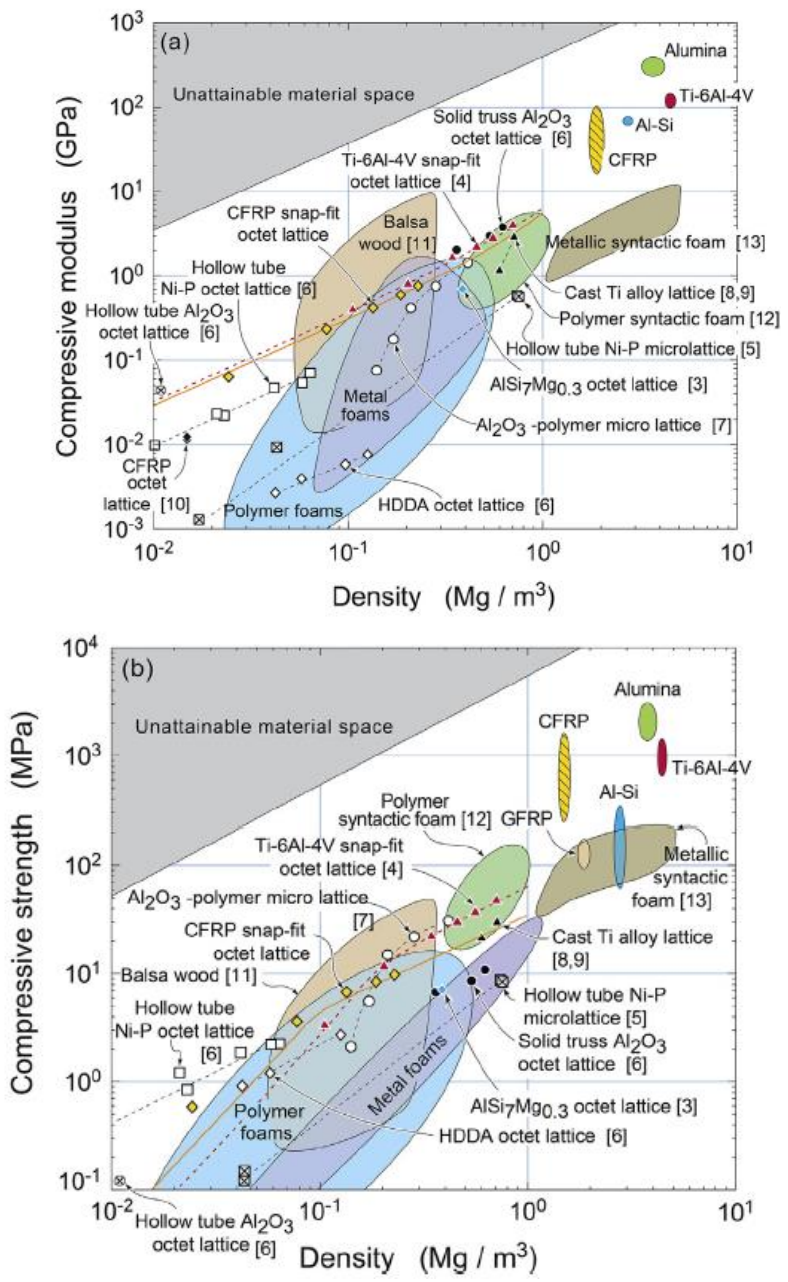

Figure 3. Comparison charts of material (a) stiffness and (b) strength under compression against density $\left(\mathrm{Mg} / \mathrm{m}^{3}\right)$. Zones that cannot be achieved under ambient conditions are indicated by the grey shaded areas [7].

Similar structures produced by electrodeposition of $\mathrm{Ni}-$ 7P $[17,18]$, were manufactured from carbon-fibre laminate composites [19] produced by investment casting methods. The modules and strengths of the foams and lattices were scaled by the raw materials [20]; however; foams are essentially more malleable and weaker than their topological counterparts (made from the same material and density). Metal alloys with low density at milimeter intervals are useful structures for strut-diameter lattice structures in stressassisted aerospace industries [9] and 3D additive production methods [21, 22]. However, the strength to weight ratio of 
aerospace materials must be extremely high; therefore, these operations remain difficult. Aluminium and magnesium alloys are widely used in this industry. As the strengthweight ratio of titanium alloys is twice or more times better than aluminium alloys, there is a special interest in these alloys in order to produce octet truss structures. In addition, numerous titanium alloys can easily exceed the limits of aluminium or magnesium-based light metal alloys at continuous service temperatures [23]. Another advantage of titanium alloys is their high corrosion strength, and they are widely used in chemical processing equipment for this reason [24]. Ti-6Al-4V is the most comprehensively used titanium alloy and makes up half of the total titanium use [24]. Its main use in aircraft structural components and turbine engines is in fasteners [25, 26]. Titanium alloy lattice structures are manufactured by using investment casting methods to provide aerospace-quality standards [27,16].

The price and confusion of the titanium investment manufacturing process is excessive, and hence, there is insufficient data on the mechanical properties of titaniumbased lattice structures as functions of relative density $[27,28]$.

This study is focusing on tensile properties of octet-truss lattice structures which built with EBM. Experiments made on five specimens that fabricated at the same time in the machine. Three specimens $(1,2,4)$ containing wall along with the lattice structure and specimen 3 do not have any addition, only lattice structure. Also a filled specimen without any pores. Purpose of producing specimens 1,2 and 4 from same CAD model is measuring consistency of EBM machine and process parameters. With the aim of determining effect of wall addition to the specimens, a comparison made between specimen 1 and specimen 3. After that, both types of specimens compared with filled specimen. Numbers of specimens are meaningless as they were given to the specimens with the order of taking out from machine plate The article should include main titles such as Abstract, Introduction, Material and methods, Results and discussion, Conclusions and References.

\section{Material and methods}

\subsection{Electron beam melting process}

All the specimens in this research were produced with ARCAM Q20. It is an EBM machine with production volume of $\varnothing 350 \times 380 \mathrm{~mm}$ and is suitable for the production of critical parts, such as turbine blades for airplanes. The electron beam melting is fully capable of producing dense metal parts. A strong electron beam $(7 \mathrm{~kW})$ is used to form a layer by melting the metal powders in accordance with the geometry obtained from the 3D CAD model. The 3D CAD model of the piece is divided into 2D slices, usually $0.1-0.07$ $\mathrm{mm}$ thick, with special software. The arithmetic mean surface roughness $\mathrm{Ra}$ is approximately $25-35 \mathrm{~mm}[28,29]$. The electron beam melting process works according to the kinetic energy principle of electrons. The electrons emitted from the filament accelerate towards a very high-speed building platform by forming an electron beam. When these electrons collide with the metal powder, the speed of the electrons decreases and the kinetic energy is transformed into thermal energy to generate heat, which melts the dust particles. The electron beam is formed in an electron beam gun comprising an anode, a cathode, and electromagnetic focus and deflection units. This gun heats up and emits electrons when the electric current passes through the tungsten filament (cathode). In the meantime, $60,000 \mathrm{~V}$ is applied to the anode at the bottom of the filament and the extremely high potential voltage difference helps accelerate the electrons from the filament in the desired direction [30]. The resulting beam is then focused on the electromagnetic coil with the help of the focus. Then, the beam is deflected by the deflection coil to special areas on the building platform at scan speeds as high as $8,000 \mathrm{~m} / \mathrm{s}$. In a previous study, the scan rate was reported as $1,000 \mathrm{~m} / \mathrm{s}$ [31]. An astigmatism coil helps to keep the beam in focus, regardless of its position on the build platform. Without the coil, the beam tends to extend from the building region to the edge, thus extending to a wider area. The whole process is conducted under vacuum. This vacuum environment overlaps the ions with those that may act as obstacles and cause the electron beam to dissipate [32, 33]. Figure 4 illustrates the components of the EBM process [34,36].

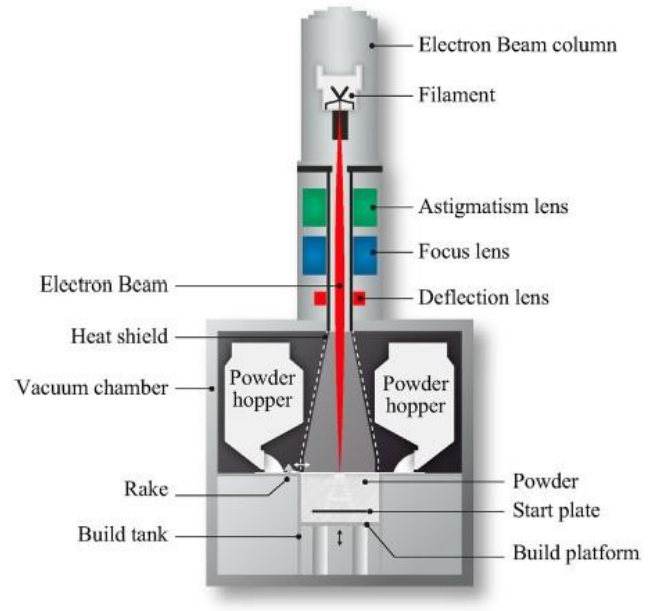

Figure 4. Main components of EBM process [30-38].

\subsection{Material properties}

Titanium alloys are commonly used in additive manufacturing technologies. In addition, titanium alloys are the most widely used materials in aerospace industries. These alloys are light-weight, and exhibit good corrosion resistance along with high strength properties. Hence, we chose to use Ti-6Al-4V in our study. According to the manufacturers, the delivered materials should have the mechanical properties listed in Table 1 .

Table 1. Key mechanical properties for EBM-produced components [37]

\begin{tabular}{cc}
\hline & EBM as-built \\
\hline Yield Strength (MPa) & 950 \\
Ultimate Tensile Strength (MPa) & 1020 \\
Elongation to Fracture (\%) & 14 \\
Hardness (HV) & 327 \\
Elastic Modulus (GPa) & 120 \\
\hline
\end{tabular}




\section{Experimental setup}

\subsection{Modelling the specimen}

In this study, the specimen was modelled with SpaceClaim [39]. First, a unit octet truss geometry was modelled, as shown in Figure 5. This unit geometry was duplicated to fill the specimen. According to the dimensions given in Table 2, the specimen modelled and shown in Figure 6.

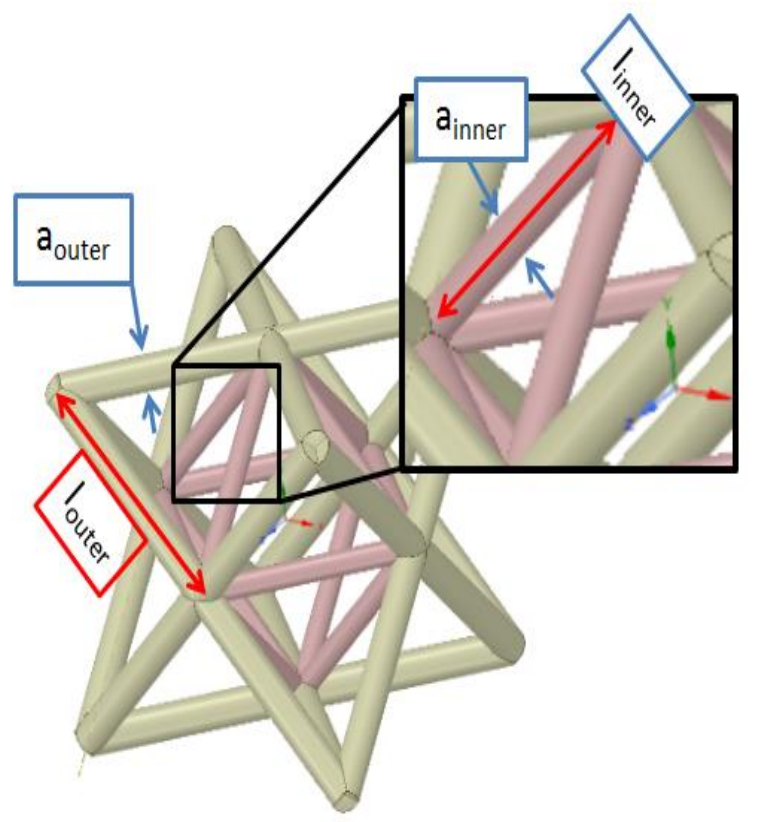

Figure 5. Unit octet truss geometry

Table 2. Details of unit octet truss geometry

\begin{tabular}{ccc}
\hline & $\begin{array}{c}\text { Inner } \\
\text { Beams }\end{array}$ & $\begin{array}{c}\text { Outer } \\
\text { Beams }\end{array}$ \\
\hline $\mathrm{a}=$ strut diameter $(\mathrm{mm})$ & 0.08 & 0.1 \\
$1=$ length of each strut $(\mathrm{mm})$ & 0.71 & 1.41 \\
\hline
\end{tabular}

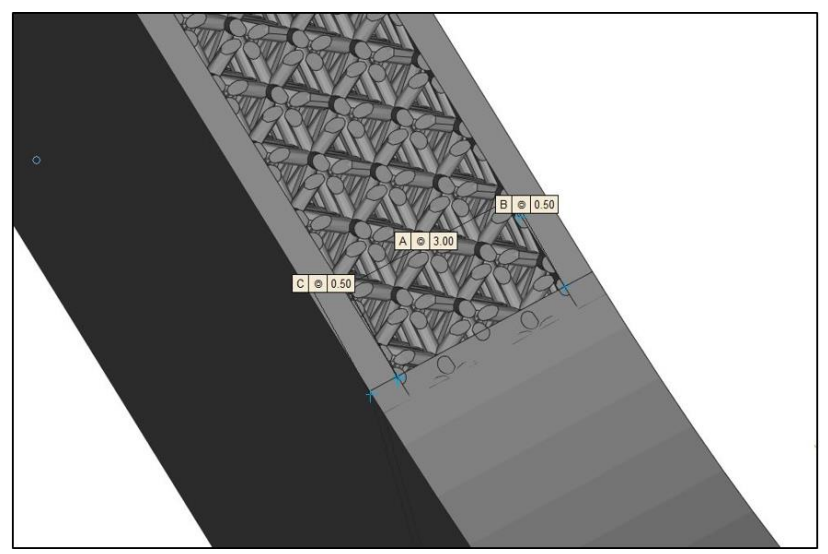

Figure 6. Isometric view of octet truss part of specimen

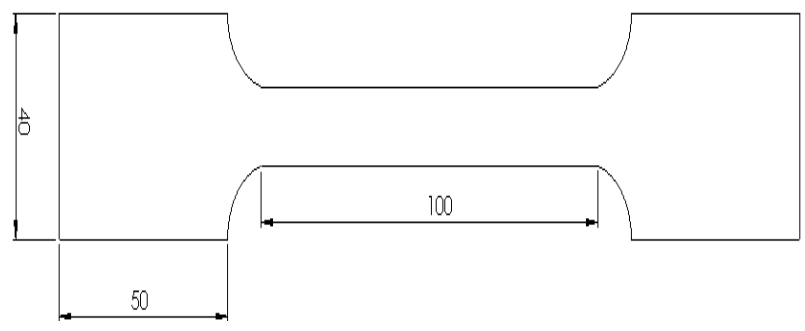

Figure 7. Specimen dimensions

Figure 7 shows the dimensions of specimens and the thickness is $4 \mathrm{~mm}$. Relative density percentage at the octettruss sections is $30 \%$ for all the specimens.

\subsection{Tensile test setup}

Tensile tests made with Instron 8802 hydraulic test machine in Figure 8 by ASTM D3039 standard [40]. Width and thickness values of specimens entered to the system with the test speed of $0.5 \mathrm{~mm} / \mathrm{min}$.

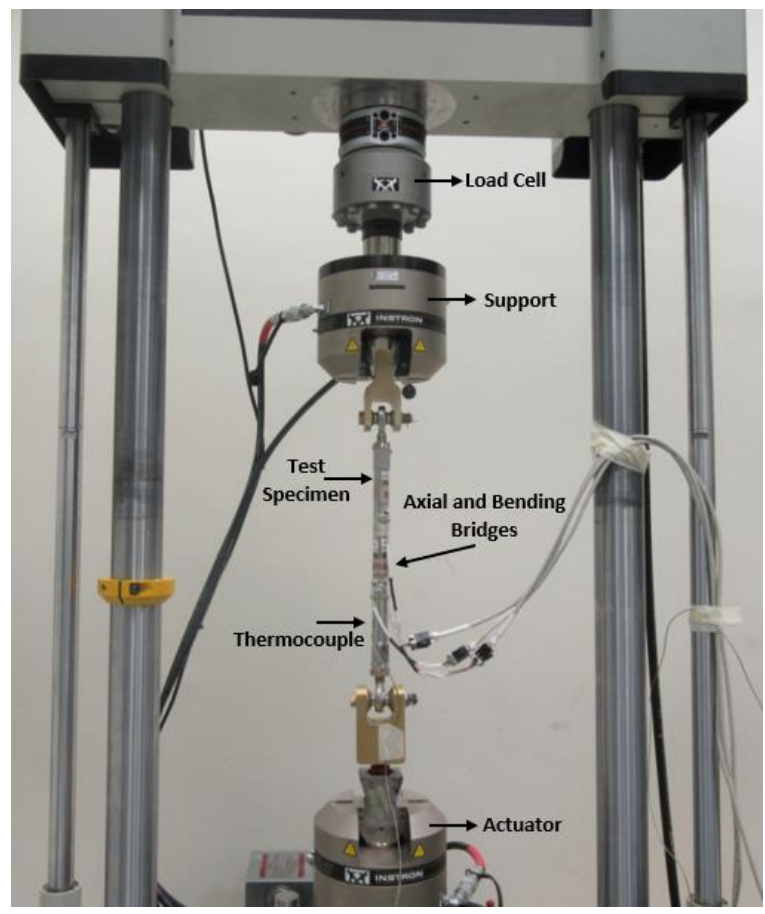

Figure 8. Tensile experiment setup

\section{Results and discussions}

Additive manufactured parts may not be accurate to the design. Due to high temperatures, non-uniform powder dimensions etc. the resulted parts are not identical even if they are based on the same design and manufacturing parameters. In order to research, the specimens $1,2 \& 4$ (Figure 9) were built using the same solid design \& process parameters and tested under the same conditions. 

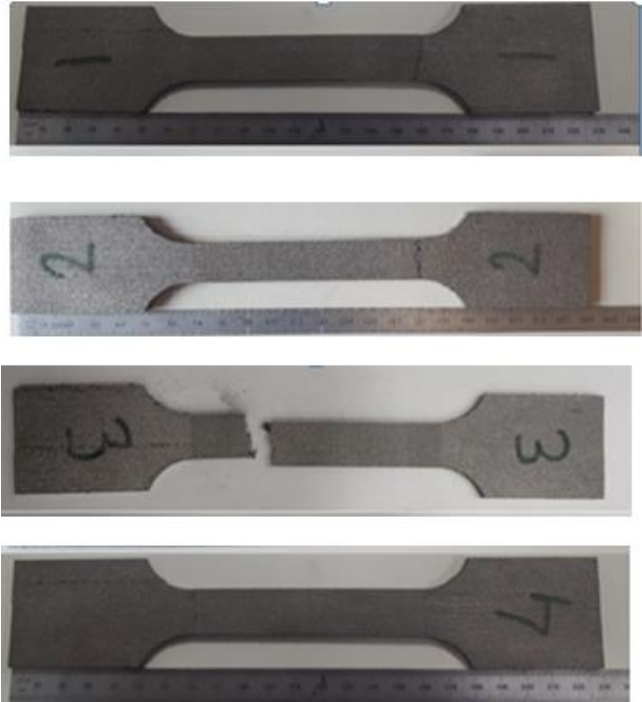

Figure 9. Octet-truss specimens

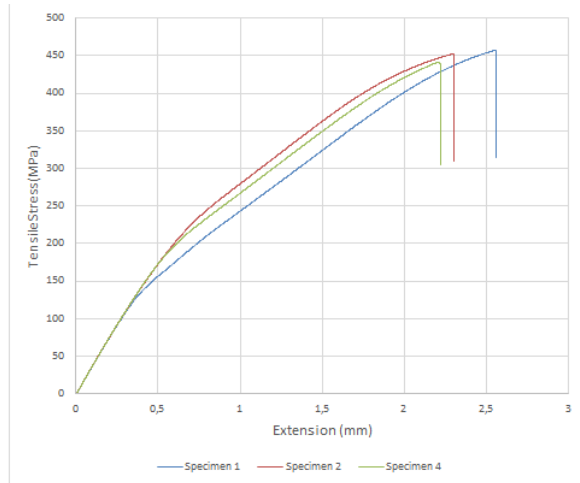

Figure 10. Tensile test data of specimens 1, $2 \& 4$

Table 3. Experimental ultimate tensile stress values of specimens $1,2 \& 4$

\begin{tabular}{cc}
\hline Specimen Number & Ultimate Tensile Stress (MPa) \\
\hline 1 (wall+lattice structure) & 457.0 \\
2 (wall+lattice structure) & 452.43 \\
3 (lattice structure only) & 211.2 \\
4 (wall+lattice structure) & 441.32 \\
\hline
\end{tabular}

Figure 10 and Table 3 shows the difference occurred due to manufacturing method. Ultimate tensile stress difference between the best performed specimen 1 and worst performed specimen 4 is $15.7 \mathrm{MPa}$ which is equal to $3.5 \%$. If the analytical results taken into account which is $474.77 \mathrm{MPa}$, the gap against specimen 1 is $17.77 \mathrm{MPa}$ and this gap is equal to $3.8 \%$.

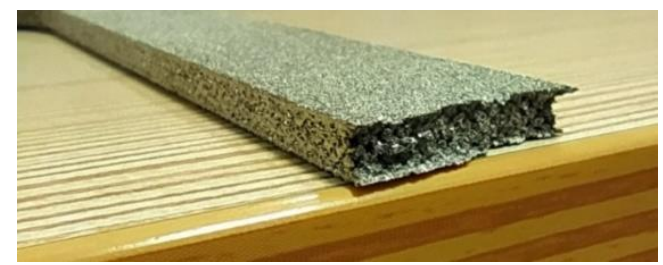

Figure 11. Specimen 1 (wall+lattice structure)

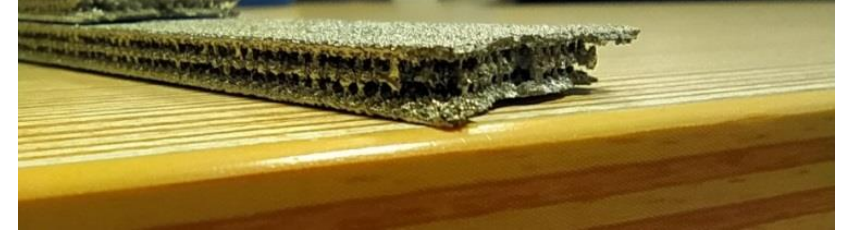

Figure 12. Specimen 3 (lattice structure only)

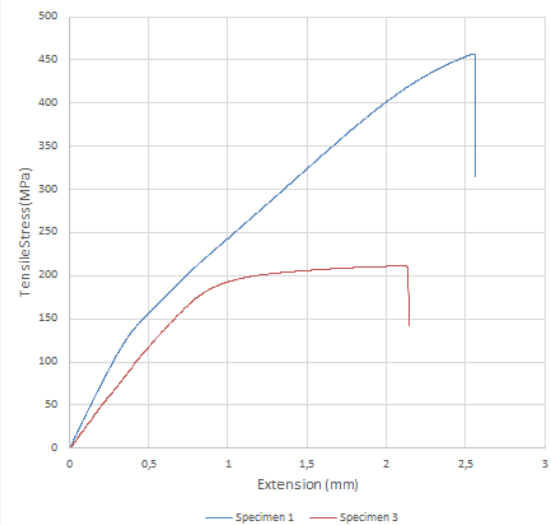

Figure 13. Tensile test data comparison of specimen $1 \& 3$

To investigate effects of wall addition on strength of the parts, specimen 3 manufactured without wall structure as shown in Figure 12. Comparing to the specimen 1, specimen 3 could achieve less than half tensile strength with a value of 211.2 MPa as can be seen in Figure 13. Considering cracks appears on the outer surfaces at the beginning, specimens consisting wall structure resisted much higher loads before failure, thus specimen 3 failed earlier due to this reason.

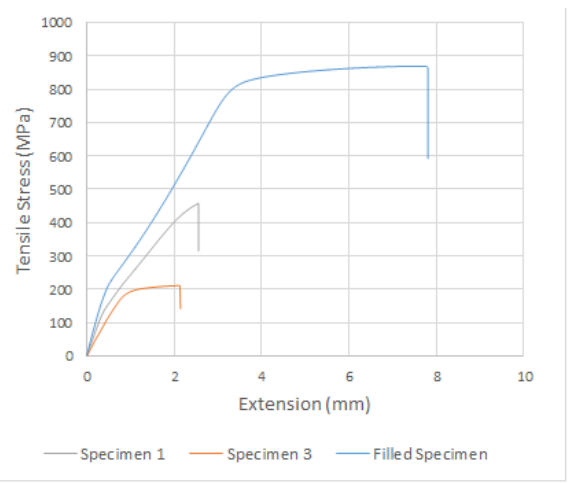

Figure 14. Tensile test data of specimen $1,3 \&$ filled specimen

The chart shown in Figure 14 represents the results from three different types of specimens. Specimen 1 which is made from wall and lattice structure, specimen 3 only lattice and also filled specimen without any empty spaces through the whole geometry. Filled specimen has 868.9 MPa tensile strength that means filled specimen is $190 \%$ better than specimen 1 and $412 \%$ better than specimen 3 in terms of tensile strength. 


\section{Conclusions}

Additive manufacturing can be considered as a recent technology. Exploring this technology to understand what are the gives and takes, determine advantages and disadvantages is a crucial task. Taking into consideration EBM is a manufacturing method, exploration mostly starts with strength of the produced parts for engineering. Also one of the promises of additive manufacturing is allowing to build complex shapes. Hence, this paper focused on these subjects. Four of the tested specimens include octet-truss structures, three of them have wall and one without it. Also a filled specimen has been built. After tensile tests, wall structure addition proved to be an effective method to increase the strength more than twice times as specimens with wall achieved $457 \mathrm{MPa}$ ultimate tensile strength comparing to the $211.2 \mathrm{MPa}$ of specimen which doesn't have wall. It adds extra weight to the part but considering the strength increase it is likely going to be neglected. Octettruss specimens are compared with the filled specimen to see the achievements of lattice structure with its $30 \%$ density. The result values are promising. EBM is a special type of powder bed fusion additive manufacturing since its heat source is electron beam, not laser. In this study, not only the strength of the octet-truss lattice but also the consistency of EBM method is investigated. Three specimens produced from the same solid model and with the same process parameters. Specimen 1 showed $457 \mathrm{MPa}$ tensile strength while Specimen 2 showed $452.43 \mathrm{MPa}$ and Specimen 4 with $441.32 \mathrm{MPa}$. If three of these specimens had the same geometry after manufacturing, then they would show almost the same ultimate tensile stress results since the tests applied on the specimens under the same conditions. Difference between the strongest and weakest specimen is $15.7 \mathrm{MPa}$ which is equal to $3.5 \%$. Depending on the designer and design, these results can be considered as significant or insignificant. Octet-truss lattice structures proved to be a worthy approach to reduce weight from the parts while still meeting the necessary strength. Additive manufacturing combined with lattice structures is an attractive combination for the studies on lightweight parts.

\section{Acknowledgement}

In the study, all of the spaceman subjected to the tensile test were produced in the Turkish aviation (TUSAS) industry. In addition, each of the tests was carried out in TUSAS facilities. We would like to thank you for the opportunities provided by the Turkish aviation industry.

\section{Conflict of interest}

The authors declare that there is no conflict of interest.

\section{Similarity rate (iThenticate): $5 \%$}

\section{References}

[1] L. Yang, Additive manufacturing of metal cellular structures: Design and fabrication. JOM: Journal of the Minerals, Metals \& Materials Society, 67(3), 608-615, 2015. https://doi.org/10.1007/s11837-015-1322-y.

[2] L. Kolbus, Comparison of residual stresses in inconel 718 simple parts made by electron beam melting and direct laser metal sintering. Metallurgical and Materials Transactions A, 46(3), 1419-1439, 2015. https://doi.org/10.1007/s11661-014-2722-2.

[3] L.E. Murr, Microstructure and mechanical behaviour of Ti-6Al-4V produced by rapid-layer manufacturing, for biomedical applications. Journal of the Mechanical Behaviour of Biomedical Materials, 2(1), 20-32, 2009. https://doi.org/ 10.1016/j.jmbbm.2008.05.004

[4] A. Saigal, J. Tumbleston, H. Vogel, C. Fox, N. and N. Mackay, Mechanical response of octahedral and octettruss lattice structures fabricated using the CLIP technology. department of mechanical engineering, Tufts University, 200 College Avenue, Medford, USA,2016. https://doi.org/10.12783/ dtcse/cmsam2016/3572

[5] D. Sypeck and H. Wadley, Cellular metal truss core sandwich structures. Advanced Engineering Materials, 759-764, 2005. https://doi.org/ 10.1007/s10443-0051129-Z.

[6] N. Z. M. Zaid, M. R. M. Rejab, and N. A. N. Mohamed, Sandwich structure based on corrugated-core: A Review. MATEC Web of Conferences 74, ICMER 2015. https://doi.org 10.1051/matecconf/20167400029

[7] L. Dong and H. Wadley, Mechanical Properties of carbon fiber composite octet-truss lattice structures. Computers Science and Technology, 26(33), 119, 2015.https://doi.org/10.1016/j.compscitech.2015.09.0 22.

[8] L. Dong, V. Deshpande and H. Wadley, Mechanical response of Ti-6Al-4V octet-truss lattice structures. International Journal of Solids and Structures, 107(124), 60-61, 2015. https://doi.org /10.1016/j.ijsolstr.2015.02.020.

[9] V. Deshpande, N. A. Fleck and M. F. Ashby, Effective properties of the octet-truss lattice material. Journal of the Mechanics and Physics of Solids, 49(8), 1747-1769, 2001. https://doi.org/ 10.1016/S0022-5096(01)000102.

[10] W. P. Syam, W. Jianwei, B. Zhao, I. Maskery, W. Elmadih and R. Leach, Design and analysis of strutbased lattice structures for vibration isolation. Precision Engineering, $2017.2017 .09 .010 . \quad$ https://doi.org/ 10.1016/j.precisioneng.2017.09.010.

[11] N.A. Fleck, An overview of the mechanical properties of foams and periodic lattice materials. Cambridge University Engineering Department, 2004.

[12] A. Vigliotti and D. Pasini, Stiffness and strength of tridimensional periodic lattices. Computational Methods Applications Mechanical Engineering, 27(43), 229-232, 2012. https://doi.org/10.1016/ j.cma.2012.03.018

[13] R.B. Fuller, 1961, Octet Truss. U.S. Patent No. $2,986,241$

[14] K. Finnegan, G. Kooistra and H.N. Wadley, The compressive response of carbon fiber composite pyramidal truss sandwich cores. Int.J.Mater.Res. 98, 1264-1272, 2007. https://doi.org10.3139/ 146.101594.

[15] Q. Li, E.Y. Chen and R.B. Douglas and D.C. Dunand, Mechanical properties of cast $\mathrm{Ti}-6 \mathrm{Al}-4 \mathrm{~V}$ lattice block 
structures. Metall. Mater. Trans. A 39, 441-449, 2008. https://doi.org10.1007/s11661-007-9440-y.

[16] Q. Li, E.Y. Chen, D.R. Bice and D.C. Dunand Mechanical properties of cast $\mathrm{Ti}-6 \mathrm{Al}-2 \mathrm{Sn}-4 \mathrm{Zr}-2 \mathrm{Mo}$ lattice block structures. Adv. Eng. Mater. 10, 939-942, 2008. https://doi.org 10.1002/ adem.200800114.

[17] A. Torrents, T.A. Schaedler, A.J. Jacobsen, W.B. Carter, and L. Valdevit, Characterization of nickelbased microlattice materials with structural hierarchy from the nanometer to the millimeter scale. Acta Mater., 60, 3511-3523, 2012. https://doi.org/10.1016/j.actamat.2012.03.007

[18] X. Zheng, H. Lee, T.H.Weisgraber, M. Shusteff, J. Deotte, E.B. Duoss, J.D. Kuntz et al., Ultralight, ultrastiff mechanical metamaterials. Science 344, 1373 1377, 2014. https://doi.org 10.1126/ science.1252291.

[19] K.C. Cheung and N. Gershenfeld, Reversibly assembled cellular composite materials. Science 341, 1219-1221, 2013. https://doi.org $10.1126 /$ science. 1240889.

[20] L.J. Gibson and M.F. Ashby, Cellular Solids: Structure and Properties. Cambridge University Press, 1999.https://doi.org/10.1017/CBO97811398783 26.

[21] D.W. Rosen, Computer-aided design for additive manufacturing of cellular structures. Comput. Aided Des. Appl. 4, 585-594, 2007.https://doi.org/ 10.1080/16864360.2007.10738493.

[22] C.B. Williams, J.K. Cochran and D.W. Rosen, Additive manufacturing of metallic cellular materials via threedimensional printing. Int. J. Adv. Manuf. Technol. 53, 231-239, 2011. https://doi.org /10.1007/s00170-0102812-2.

[23] M.K. Kulekci, Magnesium and its alloys applications in automotive industry. Int. J. Adv. Manuf. Technol. 39, 851-865, 2008. https://doi.org /10.1007/s00170-0071279-2.

[24] J.R. Couper, W.R. Penney and J.R. Fair, Chemical Process Equipment revised 2nd Edition: Selection and Design, second ed. Gulf Professional Publishing, 2009.

[25] R.R. Boyer and R.D. Briggs, The use of titanium alloys in the aerospace industry. J. Mater. Eng. Perform. 14(6), 681-685, 2005. https://doi.org $10.1361 / 105994905 \times 75448$.

[26] R. Boyer and E.W. Collings, (Eds.), Materials Properties Handbook: Titanium Alloys. ASM International, 1993.

[27] W.D. Brewer, R.K. Bird and A.W. Terryl, Titanium alloys and processing for high speed aircraft. Mater.
Sci. Eng., A 243, 299-304, 1998. https://doi.org/10.1016/S0921-5093(97)00818-6.

[28] J. Wang, A.G. Evans, K. Dharmasena and H.N.G. Wadley, On the performance of truss panels with Kagome cores. Int. J. Solids Struct. 40, 6981-6988, 2003. https://doi.org/10.1016/S0020-7683(03)003494.

[29] P. Heinl, et al., Cellular Titanium by Selective Electron Beam Melting. Adv. Eng. Mater. 9(5), 360-364, 2007. https://doi.org/10.1002/ adem.200700025.

[30] G. Chahine, et al., The Design and Production of Ti6Al-4V ELI Customized Dental Implants. JOM November, 60, 50-55, 2008. https://doi.org /10.1007/s11837-008-0148-2.

[31] E.F. Bradley, Superalloys; A Technical Guide; ASM International: Materials Park, OH, 1988.

[32] S. Biamino, et al., Electron Beam Melting of Ti-48Al$2 \mathrm{Cr}-2 \mathrm{Nb}$ Alloy: Microstructure and Mechanical Properties Investigation. Intermetallics 19, 776-781, 2011. https://doi.org/ 10.1016/ j.intermet.2010.11.017.

[33] M. Cronskär, The Use of Additive Manufacturing in the Custom Design of Orthopedic Implants. Thesis for the degree of Licentiate of Technology, Östersund, Sweden, 2011.

[34] L.E. Murr, et al., Advanced Metal Powder Based Manufacturing of Complex Components by Electron Beam Melting. Mater. Technol., 24(3), 180-190, 2009. https://doi.org/10.1179/106678509X12475882446133.

[35] L.E. Murr, et al., Metallographic Characterization of Additive-layer Manufactured Products by Electron Beam Melting of Ti-6Al-4V Powder. Pract. Metallogr, 46, 442-453, 2009. https://doi.org/10.3139/147.110036.

[36] S.M. Gaytan, et al., Structure-property process Optimization in the Rapid-layer Manufacturing of Ti6Al-4V Components by electron beam melting. tms. in supplemental proceedings: Fabrication, materials, Processing and Properties, 1, 363-369, 2009.

[37] ARCAM A2, Setting the Standards for AdditiveManufacturing,http://www.arcam.com/wpcontent/uploads/Arcam-Ti6Al4V-Titanium Alloy.pdf , 2011.

[38] L. Wei, et al., Scan Strategy in Electron Beam Selective Melting. Tsinghua Sci. Technol. 14(1), 120-126, 2009. https://doi.org/10.1016/S1007-0214(09)70078-1.

[39] Ansys SpaceClaim https://www.ansys.com/ products/3d-design/ansys-spaceclaim.

[40] ASTM INTERNATIONAL http://www.astm.org/ cgibin/resolver.cgi?D3039D3039M 